\title{
Supporting science learning in linguistically diverse classrooms: Factors related to the use of bilingual content in a computer-based learning environment
}

\author{
Evelien Van Laere ${ }^{a,}$, , Orhan Agirdag b, c, Johan van Braak ${ }^{a}$

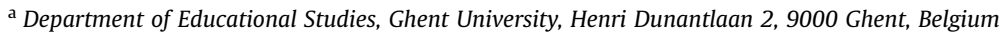 \\ ${ }^{\mathrm{b}}$ Department of Educational Sciences, University of Amsterdam, Nieuwe Achtergracht 127, 1018 WS Amsterdam, The Netherlands \\ ${ }^{\mathrm{c}}$ Education and Society, University of Leuven, Andreas Vesaliusstraat 2, 3000 Leuven, Belgium
}

\section{A R T I C L E I N F O}

\section{Article history:}

Received 11 August 2015

Received in revised form

8 December 2015

Accepted 20 December 2015

Available online $\mathrm{xxx}$

\section{Keywords:}

Bilingual content

Computer-based learning environments

Elementary education

Language minority students

Multilevel analysis

Support in home language

\begin{abstract}
A B S T R A C T
Computer-based learning environments (CBLEs) are a promising means to support language minority (LMi) students in acquiring knowledge and skills through the integration of authentic support in their home language. This study aimed to determine the use of scientific bilingual content offered to fourthgrade students $(\mathrm{n}=250)$ in the CBLE E-Validiv and to identify both student and classroom characteristics related to this use. All the content in E-Validiv is accessible in the language of instruction and one of six other languages. For LMi students, the other language is set to their home language. Multilevel hierarchical regression analyses show that especially LMi students who assess themselves as highly proficient in their home language use the content more in the other language than language majority students. However, even LMi students focus mainly on content in the language of instruction, which indicates that they particularly apply their home language to support their learning process in the language of instruction. Additionally, students who perform higher on science subjects access content more in the language of instruction. The presence of linguistic diversity in the classroom and the positive use of linguistic diversity by the teacher do not seem to matter. The theoretical and practical implications are discussed.
\end{abstract}

() 2015 Elsevier Ltd. All rights reserved.

\section{Introduction}

In general, and particularly for the domain of science education, language minority (LMi) students often face a great challenge to attain the same performance level than language majority (LMa) students. While LMi students are defined as students who use a language at home that is different from the language of instruction (LOI) applied at school, LMa students have the same home language as the LOI. This achievement gap between LMi and LMa students has been identified in large-scale studies, indicating that students with another home language than the LOI run a higher risk to perform weakly on science subjects (e.g. Bellens, Arkens, Van Damme, \& Gielen, 2013; Maerten-Rivera, Myers, Lee, \& Penfield, 2010; Martin, Mullis, Foy, \& Stanco, 2012; OECD, 2009, 2010; Van Laere, Aesaert, \& van Braak, 2014). However, while LMi students' home language is often excluded from classroom practice, it could

\footnotetext{
* Corresponding author.

E-mail address: evelien.vanlaere@ugent.be (E. Van Laere).
}

also be considered as a resource to support their learning process and thus help to bridge the achievement gap (Cummins, 2001). Yet, more research is needed on how this can be realized, for example by means of educational technology.

One of the main reasons put forward for the observed achievement gap is that LMi students are confronted with a double challenge (Goldenberg, 2008). All students, including LMa students, must become proficient in the literacy skills needed to develop scientific knowledge and skills (Cummins, 1979; Fang, 2006; Shanahan \& Shanahan, 2008). These skills comprise the mastery of a specific scientific language, typified by a complex vocabulary and grammar, an underlying assumption of causal relationships, abstract thinking, and restricted support from the surrounding context (Curenton \& Justice, 2004; Fang, 2006; Hiebert \& Lubliner, 2008; Van den Branden, 2010). While LMa students need to acquire these new literacy skills in the LOI, LMi students face an additional problem. LMi students must not only learn these skills, just like LMa students. They also have to master these skills in the LOI, while they are often still struggling to become proficient in the LOI. 
Moreover, LMi students' home language is often considered as an obstacle for their learning process, especially when it is regarded as a less prestigious language (Agirdag, 2010; Goriot, Denessen, Bakker, \& Droop, 2015; Shannon, 1995). As a consequence, the focus in most schools exclusively lies on learning in and through the LOI (Auerbach, 1993; Kenner, Gregory, Ruby, \& Al-Azami, 2008; Riches \& Genesee, 2006). However, Baker (2011) suggests that the present achievement gap can be linked to the neglect of the expertise students have already built up in their home language. As an alternative, their home language can also be called upon to support their learning process (Cook, 2001; Jiménez, García, \& Pearson, 1996; Kempert, Saalbach, \& Hardy, 2011; Msimanga \& Lelliott, 2014; Sierens \& Van Avermaet, 2014).

Nevertheless, it is a great challenge to include every student's home language as many classrooms are characterized by a moderate to large linguistic diversity, particularly in urban areas. This puts a high demand on both daily classroom practices and students' achievement throughout their school career (Sierens \& Van Avermaet, 2014). Moreover, teachers do not have the resources to attend to and support every student in his/her home language (Clark, Touchman, Martinez-Garza, Ramirez-Marin, \& Drews, 2012). Educational technology, and more specifically the development of computer-based learning environments (CBLEs), can offer new pathways to respond to this challenge. First, CBLEs can offer content in different languages through different pathways (Pederson, 1986). Next, they can be a powerful means to foster students' acquisition of complex knowledge and skills (Lajoie \& Azevedo, 2006; Zhang et al., 2015). Finally, recent research offers promising results of CBLEs as an educational means to realize multilingual education, for example by offering authentic language support in the home language (Clark et al., 2012).

However, more research is needed into how students interact with complex CBLEs and which characteristics are related to this (Clarebout \& Elen, 2006; Proctor, Dalton, \& Grisham, 2007; Snow, Jackson, \& McNamara, 2014; Zhang, Ordóñez de Pablos, \& Xu, 2014). This can offer new insights for the theoretical development, the design as well as the practical use of these CBLEs. Research on how bilingual content, and more specifically the support in the home language, is approached in CBLEs is still very limited. Moreover, the use of code-switching has not yet been studied in the context of CBLEs. Code-switching, which refers to the shifting between languages by appealing to someone's whole linguistic repertoire, is a skill that is common in people who are highly proficient bilinguals (Canagarajah, 2011; Liebscher \& Dailey-O'Cain, 2005). It can be used in a conversation (e.g., Bono \& Melo-Pfeifer, 2010), but also in other contexts, such as writing (e.g., Losey, 2009) or reading (e.g., Ng, Gonzalez, \& Wicha, 2014).

Therefore, the purpose of this study is to gain insight into how students approach bilingual content (i.e. in the LOI and another language) offered in a CBLE focusing on science education. Furthermore, we will examine student and classroom characteristics related to students' time spent on content offered in the two languages and the associated activity of code-switching. Special focus will be put on LMi students' use of the bilingual content as they have access to their home language in the CLBE. In what follows, we will first argue why LMi students' home language can be a valuable tool to support knowledge acquisition. Next, we will take a closer look at code-switching. Finally, we will review factors that are likely to be connected to the use of bilingual content in CBLEs.

\section{Background}

\subsection{The home language: a valuable tool for learning}

Language is one of the main symbolic tools children learn to master (Vygotsky, 1978). As LMi students' home language is mostly the first language they have learned, they regulate their cognitive processes through it and apply it as a cognitive tool to mediate their learning process in the LOI (Lantolf, 2000; Lantolf \& Thorne, 2007; Swain \& Lapkin, 2000; Vygotsky, 1978). This is in line with Cummins' (1979) linguistic interdependence hypothesis, which states that the level of competence in the LOI is strongly related to and influenced by the type of competence the student has already developed in his/her home language. Through a common underlying proficiency, knowledge and skills can transfer across languages, thereby strengthening literacy in both the home language and the LOI (Bialystok \& Hakuta, 1999; Duibhir \& Cummins, 2012; Genesee, Geva, Dressler, \& Kamil, 2006; Riches \& Genesee, 2006). Thus, LMi students can appeal to their own expertise in their home language as a support tool to acquire knowledge and skills in the LOI (Upton \& Lee-Thompson, 2001). This empowers them to take the next level, just beyond what is possible to accomplish independently (Freeman \& Crawford, 2008; Vygotsky, 1978; Wood, Bruner, \& Ross, 1976).

As a cognitive tool, the home language may serve different functions. First, it can act as an important information source to construct meaning (e.g. Goodrich, Lonigan, \& Farver, 2013; Jiménez, García, \& Pearson, 1995, 1996; Langer, Bartolome, Vasquez, \& Lucas, 1990; Proctor, August, Carlo, \& Snow, 2006). In line with this, it can appeal to prior knowledge already developed in the home language (Butzkamm, 1998; Fung, Wilkinson, \& Moore, 2003; Jiménez et al., 1995, 1996; Kenner et al., 2008). Third, it can stimulate metalinguistic awareness as a way of thinking about how things are expressed in different languages (Kenner et al., 2008; MartinBeltrán, 2010). Finally, it can make the curriculum content more accessible through solving missing links when students have not yet acquired the appropriate knowledge in the LOI (Clark et al., 2012; Kenner et al., 2008; Riches \& Genesee, 2006). As a consequence, the use of the home language has the potential to facilitate classroom activities and foster high-level educational achievement, particularly in the context of complex tasks (Alegría de la Colina \& del Pilar García Mayo, 2009; Swain \& Lapkin, 2000). Students with an immigrant background and a low academic proficiency may profit from integrating their home language in the learning process, thereby allowing them to work at a higher cognitive level than what would be possible if they could only use the LOI (Kempert et al., 2011; Storch \& Wigglesworth, 2003).

Valuable efforts have already been undertaken to integrate support in the home language into CBLEs. Examples of such CBLEs in compulsory education are HELP Math (Freeman, 2012; Freeman \& Crawford, 2008), the Universal Literacy Environment (Dalton \& Proctor, 2007; Proctor et al., 2011), and the Wolves Project (Clark et al., 2012). However, the research on these CBLEs mostly takes into consideration a whole range of different support tools, without focusing on the home language support in itself. As a consequence, no conclusions can be drawn about the added value of offering bilingual content to students from different linguistic backgrounds. An exception to this is the study by Clark et al. (2012). They have compared the influence of providing supports only in the LOI versus providing supports in both the home language and the LOI in an online science inquiry environment. The results show that LMi students gain greater understanding about science topics in the LOI when they have access to the content and supports in both their home language and the LOI, in comparison with the LOI-only format (Clark et al., 2012). However, it is necessary to take a step backwards and first determine the factors related to students' use of the bilingual content before its potential for raising achievement can be identified. Additionally, most CBLEs are focused exclusively on Spanish-English bilinguals, as this is one of the most represented groups of bilingual learners in the U.S. (e.g. Proctor et al., 2011). In 
light of the cultural and linguistic diversity in societies around the world, there is a serious need to serve students with different home languages (e.g. Clark et al., 2012; Kenner et al., 2008) while at the same time promoting language awareness of all children, including monolingual speakers. To conclude, more research is needed to get a clearer picture of whether and how instruction in CBLEs offering bilingual content, and especially appealing to students' home language, can support the learning process in the LOI.

\subsection{Code-switching: getting access to more than one language}

Code-switching can be defined as the "systematic alternating use of two languages or language varieties within a single conversation or utterance" (Liebscher \& Dailey-O'Cain, 2005, p. 235). A code-switch is a "complete shift to the other language for a word, a phrase or a sentence" (Grosjean, 1998, p. 137). For example, a student can explain something to a peer in the LOI but can shift to their shared home language when he/she experiences the peer does not understand everything in the LOI. The context in which most of the research on code-switching is done is that of verbal conversations (e.g., Bono \& Melo-Pfeifer, 2010; Chanseawrassamee \& Shin, 2009; Chitera, 2009). However, it can also be studied in the context of, for example, writing (e.g., Canagarajah, 2011; Losey, 2009) or reading (Edwards, Monaghan, \& Knight, 2000; Ng et al., 2014; Wang, 2015). Hence, code-switching is not limited to active speech production.

Whereas code-switching used to be judged as a random process indicating poor mastery of at least one language, it is now recognized as a complex skill that requires a large degree of linguistic competence in both languages (Poplack, 1980; Reyes, 2004; Söderberg Arnfast \& Normann Jørgensen, 2003). However, while code-switching is a widespread natural and purposeful phenomenon among bilingual language communities, it is still rarely acknowledged as a tool for cognitive development in the classroom context (Macaro, 2005; Reyes, 2004) and therefore even prohibited (Moodley, 2007). Yet, code-switching has not been shown to have a negative effect on academic achievement or cognitive development (Riegelhaupt, 2000; Unamuno, 2008). Moreover, when teachers prohibit code-switching in their classroom practice, this can lead to a reduction in student-teacher interaction and fewer complex linguistic input (Macaro, 2005).

According to Ferguson (2009), code-switching should be considered more as a pedagogic resource in the classroom. On the one hand, it can foster the development of enriched conceptual knowledge in both languages through effectively integrating content and language, thus supporting learning (Moore, 2002). For example, research has shown that students use code-switching to explain difficult concepts to each other, to enhance their vocabulary (e.g. by providing equivalents in their home language), and to develop ideas through discussion (Moodley, 2007; Willans, 2011). In this way, they can construct and transmit knowledge (Ferguson, 2003). On the other hand, code-switching can reduce cognitive overload in working memory (Butzkamm, 1998; Ferguson, 2009; Jiménez et al., 1995; Scott \& de la Fuente, 2008; Storch \& Wigglesworth, 2003). It can be very challenging to understand difficult subject matter in the LOI if students do not yet master the LOI sufficiently. Having access to their home language can free space in working memory in favor of a focus on meaning and more complex cognitive processes (Macaro, 2005; Moodley, 2007; Moore, 2002). Through code-switching, students can also relate new linguistic and conceptual knowledge to what they already know and revise their prior knowledge (Moore, 2002).

In sum, the integration of two languages by means of codeswitching can foster deep knowledge and skill acquisition in content areas across and between languages, especially for bilingual learners (Celic \& Seltzer, 2011; Unamuno, 2008). Not taking the opportunities code-switching provides may restrict the whole array of possible classroom activities, as it is an important communication strategy appealing to the knowledge and skills students have already constructed in, for example, their home language (Macaro, 2005). However, code-switching should be used strategically, namely in a way that students decide for themselves when it is useful to switch to the other language, thereby learning more than if they had not switched (Macaro, 2005; Moodley, 2007). Students can employ code-switching spontaneously, but the switching between languages can also be explicitly stimulated as a learning strategy to help them apply it more efficiently (Duibhir \& Cummins, 2012; Jiménez et al., 1996). The focus should then lie on teaching them how and when to use-code switching (Söderberg Arnfast \& Jørgensen, 2003).

While different studies have shown the potential benefits of code-switching, more research is needed to understand in what way code-switching can contribute to the learning process, particularly in the context of reading and, related to this, comprehension. Moreover, to our knowledge, the use of code-switching has not yet been studied in the context of CBLEs integrating content in different languages. For example, Clark et al. (2012) have studied the impact on the achievement of students having access to information in both their home language and the LOI; they have not focused on the process of code-switching during the use of the CBLE.

\subsection{Characteristics that are likely to play a role in the use of bilingual content in a CBLE}

Research that explicitly focuses on characteristics related to the use of bilingual content in the context of CBLEs is still very scarce. In what follows, we will look at studies that directly or indirectly offer insight into which student and classroom characteristics are likely to play a role in the use of CBLEs in general and the approach of bilingual content in particular.

With regard to student characteristics, section 2.1 and 2.2 have indicated that support given in the home language may be a viable way for LMi students to increase their achievement. However, the role of LMi students' home language in CBLEs offering content in different languages is still very limited (Clark et al., 2012). Moreover, the proficiency in the home language may be particularly crucial in the way students approach the content: literacy in the home language needs to be developed to a certain degree to benefit literacy in the LOI (Cummins, 1979; Farrell, 2011; Lanauze \& Snow, 1989; Riches \& Genesee, 2006; Yeung, Marsh, \& Suliman, 2000). For example, research has shown that LMi students successful in reading are successful in both their home language and the LOI, whereas unsuccessful readers are unsuccessful in both languages (Langer et al., 1990; Jiménez, 2000; Jiménez et al., 1996). In the context of peer interaction for science activities, Reyes (2004) showed that bilingual students mostly use the language in which they are most competent. Finally, bilingual students who are more fluent and balanced in both languages tend to employ codeswitching more efficiently as a communication strategy, which implies that there is a positive relationship between codeswitching and the proficiency in both languages (Gort, 2012; Poplack, 1980; Reyes, 2004).

In line with this, proficiency in the LOI may also play a role in the way bilingual content in CBLEs is accessed. For example, Wang (2003) has shown that students who are highly proficient in the LOI (i.c. English) may profit from switching to their home language to write high-quality texts in the LOI. In contrast, students with a low proficiency in the LOI often failed to use their home language strategically to complete the writing task. Moreno and Duran (2004) found that students with limited proficiency in the LOI 
(i.c. English), who received verbal guidance in a discovery-based multimedia game about the number line, accessed the explanations in their home language (i.c. Spanish) significantly more than students with a high proficiency in the LOI. We focus on reading ability as a measure for proficiency in the LOI because the comprehension of content area texts becomes more and more important in the second half of primary school (Shanahan \& Shanahan, 2008; Taboada, 2012). Moreover, reading in CBLEs can put a high demand on students in terms of control because they have to find their way around independently (Klois, Segers, \& Verhoeven, 2013). As such, individual differences in reading ability can influence the way students interact with CBLEs (Snow et al., 2014). Besides, being proficient in reading comprehension significantly contributes to students' performance on science subjects (Maerten-Rivera et al., 2010; O'Reilly \& McNamara, 2007; Taboada, 2012; Van Laere et al., 2014), which is the focus of the CBLE in this study. This becomes even more critical when students speak a home language that is different from the LOI, with LMi students particularly lagging behind on comprehension skills (August, Carlo, Dressler, \& Snow, 2005; Proctor, Carlo, August, \& Snow, 2005). As the CBLE for this study is built up of content area texts related to science topics, students' science achievement can also serve as an important precursor to understand the content offered to them in different languages. LMi students struggle to meet the same demands for science achievement as LMa students when only instructed in the LOI (Martin et al., 2012; OECD, 2009, 2010; Van Laere et al., 2014). As a consequence, LMi students may approach bilingual content in a CBLE in different ways if they have their home language available.

Previous studies have shown that background characteristics, such as gender and socioeconomic status (SES) are also relevant in examining learning processes in a computer-based context. For example, boys and girls tend to approach computer tasks in a different way: while boys focus especially on technical tasks, girls address the learning process more (Volman, van Eck, Heemskerk, \& Kuiper, 2005). However, when competences regarding Information and Communication Technology (ICT) are measured directly, girls perform at a higher level for both technical skills and higher-order ICT competences than boys (Aesaert \& van Braak, 2015). Moreover, research has reported gender differences in cognitive processing within CBLEs (Grimley, 2007). For example, Pöhnl and Bogner (2012) found girls and boys to differ in instructional efficiency, resulting in higher long-term learning success for girls. In other words, the same instructional design of a given CBLE can result in different outcomes, according to students' gender. Furthermore, research results regarding the relationship between SES and the use of educational technology remain inconclusive. For instance, Volman et al. (2005) found ethnic minority students to assess themselves as less skilled computer users than majority students. They also use the computer more for drill and practice than for gathering information and preparing presentations. Moreover, students in vocational education, who on average come from a lower socio-economic background, tend to report a more negative experience with, use of and beliefs towards computers (van Braak \& Kavadias, 2005). However, Tondeur, Sinnaeve, Van Houtte, and van Braak (2011) did not find SES to affect the computer-use profile of young people.

Although it can be expected that the use of bilingual content in CBLEs is most strongly related to students' individual characteristics, specific aspects within the classroom context may also have an impact on its use. For example, students being part of heterogeneous classrooms (i.e. classrooms with a broad range of different home languages available, next to the LOI) spend a lot of time in a context where linguistic diversity is strongly present (Gogolin, 2002). Therefore, they may be triggered to apply the bilingual content in their learning process. In contrast, students in homogeneous classrooms (i.e. classrooms with only limited or no other home languages available, next to the LOI) may be less inclined to go to content in another language as they are not directly confronted with this linguistic diversity. Furthermore, an environment in which teachers give attention to the present linguistic diversity in a positive way and deploy it intentionally in their students' learning process may offer opportunities for students to use different languages (Goriot et al., 2015; Kenner et al., 2008). This may also make them more willing to access content made available in other languages in a CBLE. For example, Muller and Baetens Beardsmore (2004) report on the European Hours project, in which the use of different languages is accepted as there is no single shared common language between teachers and pupils. This legitimizes all students' linguistic repertoires inside the school and allows them to apply them as temporary communication bridges. As such, language is not per se threatening, mistakes are accepted, and code-switching and translation become recognized strategies.

\section{Aim of the study}

The aim of the present study is to examine the way in which primary school students use bilingual content offered to them in a CBLE focused on science education. On the one hand, we will explore students' approach of the content in two different languages (i.e. the LOI and one of six other languages). On the other hand, we will identify both student and classroom characteristics that are related to the use of the bilingual content by students from different linguistic backgrounds. Special attention is hereby given to the way in which the bilingual content is addressed by LMi students who have their home language available in the CBLE. Accordingly, the following research questions guide the study:

1. Do student characteristics regarding their home language, background, and learning achievement relate to the time dedicated to the content in both languages in the CBLE?

2. Do classroom characteristics regarding the presence of linguistic diversity and the positive use of linguistic diversity by the teacher relate to the time dedicated to the content in both languages in the CBLE?

3. Do student characteristics regarding their home language, background, and learning achievement relate to the activity of code-switching in the CBLE?

4. Do classroom characteristics regarding the presence of linguistic diversity and the positive use of linguistic diversity by the teacher relate to the activity of code-switching in the CBLE?

\section{Method}

\subsection{The CBLE E-Validiv}

E-Validiv (www.e-validiv.be) is a CBLE, developed within the context of the broader Validiv-project (Valorizing Linguistic Diversity in Multiple Contexts of Primary Education). This CBLE is aimed at teaching fourth- and fifth-grade students about topics within the domain of science education (e.g. nature, technique, time and space, society, ...). What makes this CBLE unique, is its multilingual character: all content is offered in two different languages, namely the LOI (i.c. Dutch) and one of six other languages (OLs, i.c. English, French, Italian, Polish, Spanish, or Turkish). Throughout the CBLE, students have access to exactly the same content in both languages. They can switch between the two languages by means of a language switch button, which can be found at the top of the screen in the form of a globe (see Fig. 1). 
An individual approach can be adopted in E-Validiv as the OL can be fixed according to a student's linguistic background. More specifically, for LMi students who have their home language available in E-Validiv, the OL is set to their home language. For example, a student who speaks Turkish at home can go through EValidiv in Dutch and Turkish. In this way, LMi students' home language can be integrated in the learning process as a support tool for knowledge acquisition. For LMa students and LMi students whose home language is not available in E-Validiv, the OL is set to French or English, as these are the first two languages students encounter in foreign language education. Most of the time, students have already come into contact with these languages before formal education begins, for example through television, Internet, and computer games (Kuppens, 2007).

Not only do CBLEs such as E-Validiv offer students authentic language support through an individual approach, they can also register and save students' activities in logfiles through the use of trace methodology. To get access to E-Validiv, every student received a personal user name and password. From the moment students were logged in, all their relevant actions were registered. This asset of CBLEs is especially valuable to keep track of students' performance on the one hand and their use of support tools on the other hand (Butler \& Lumpe, 2008; Hannafin \& Land, 1997). This can shed light on the way the use of the bilingual content relates to learning, thereby clarifying the nature of learning (Pea, 2004). For example, loggings on the use of the language switch button have the potential to offer more insight into the process of codeswitching, as it makes the activity of switching between languages explicit. Moreover, according to Greene and Azevedo (2007), trace data are more accurate than self-report measures,
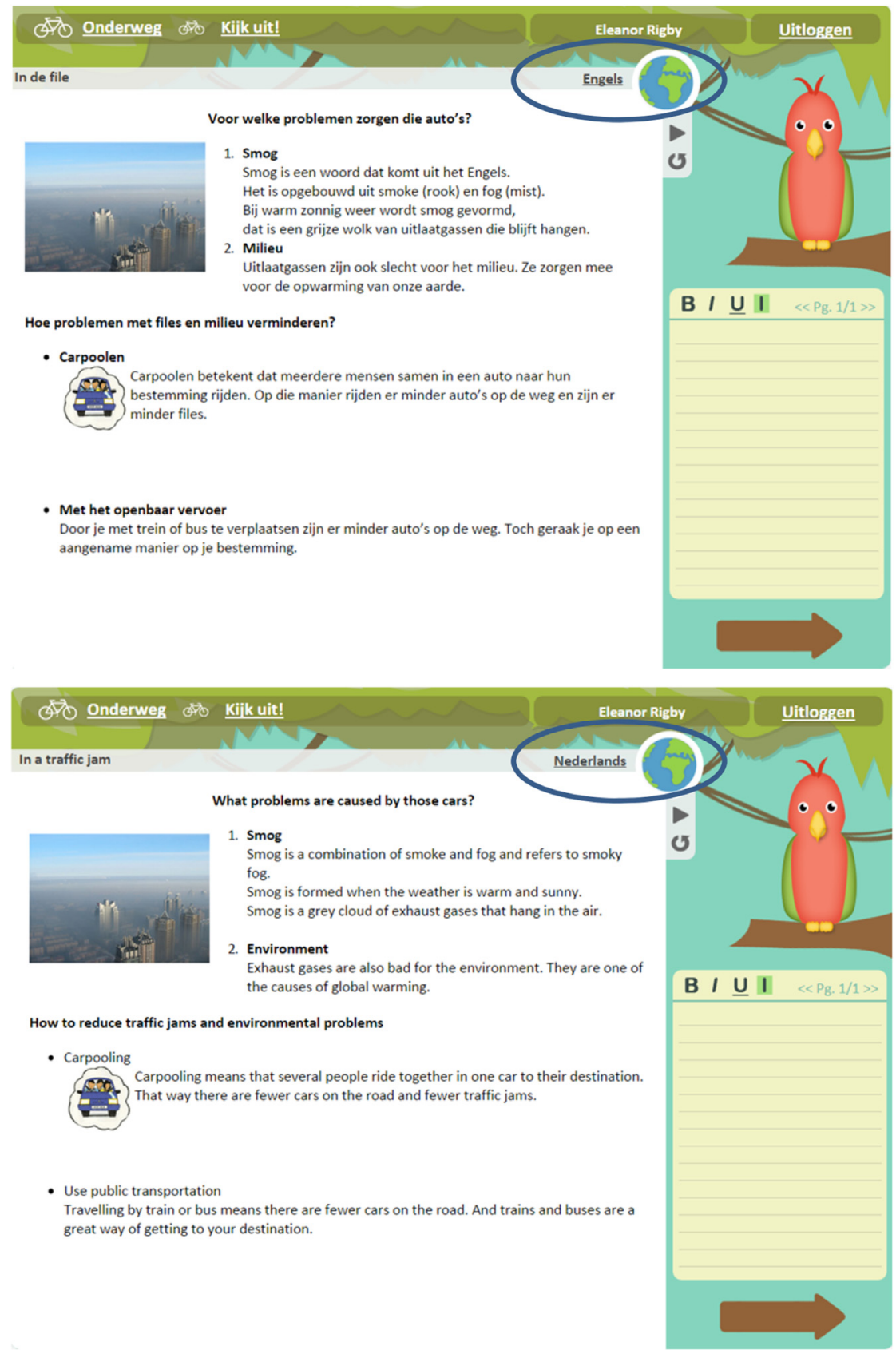

Fig. 1. Screenshot of a page in E-Validiv in the LOI (i.c. Dutch) and an OL (i.c. English), accessed via the language switch button. 
because they are based on objective data instead of on perceptions.

\subsection{Participants}

We used data from 250 fourth-grade students (mean age $=9.84$ years; $46.4 \%$ girls; $53.6 \%$ boys), their parents, and their classroom teachers $(n=35)$. For reasons of comparison, we only included LMi students who have their home language available in E-Validiv $(\mathrm{n}=132)$ and LMa students $(\mathrm{n}=118)$. LMi students who did not have their home language available were excluded from the study as the bilingual content does not directly relate to the language they use at home. The students were part of 35 classrooms in 24 primary schools participating in the Validiv-project. This sample was based on the random selection of 214 primary schools in three regions (i.e. Brussels, Ghent, and Limburg) situated in Flanders, the northern part of Belgium. The Validiv-project was proposed to all schools and $31.30 \%$ of them decided to participate. Non-response analyses revealed that the likelihood to join the project was not related to school characteristics, such as linguistic composition, denomination, school size, and school region. Half of the participating schools received access to the CBLE E-Validiv for their fourth-grade students.

\subsection{Procedure}

At the start of the project, the students were administered a paper-and-pencil test involving three parts: a survey regarding student background characteristics, a reading performance test, and a science achievement test. One of both parents was also asked to provide background information on the languages used at home and their profession through a paper-and-pencil survey. Finally, students' classroom teachers answered questions about the ways they deploy the present linguistic diversity in their classroom practice.

Every student received access to E-Validiv for a period of five months. As all the available subthemes were open to the students, they could choose independently or in consultation with the teacher which one they would go through. For this study, we have chosen to analyze the activity in one subtheme during a regular class period (=50 min), namely the subtheme which was completed by the largest number of students. In this way, we can ensure that all students performed actions on the same content (i.e. about traffic and pollution). Students had already gained experience with the CBLE beforehand through completion of an introduction theme.

\subsection{Measures}

\subsubsection{Dependent variables}

With regard to the time dedicated to the content in both languages (cf. research question 1), the time spent in both the OL and the LOI was determined via the logging. Moreover, the use of the language switch button to go to the OL or to the LOI is considered as an explicit expression of the activity of code-switching (cf. research question 2). For reasons of interpretation, all dependent variables are set to proportions. In this way, the total amount of time spent in completing the subtheme is distributed between a percentage of time spent in the OL and a percentage of time spent in the LOI, together constituting $100 \%$ of time spent in the E-Validiv subtheme. The same procedure was followed to determine the use of the language switch button.

\subsubsection{Explanatory variables at student level}

With regard to the characteristics related to students' home language, both students' status in E-Validiv and the proficiency in their home language were considered. For students' status in EValidiv, a distinction is made between LMi students for whom the $\mathrm{OL}$ is their home language and LMa students for whom the OL is set to a foreign language. Therefore, it was first determined whether students belonged to the group of LMi students or LMa students. Students were asked which language they spoke with both of their parents on a 5 -point Likert-scale ( 1 = always Dutch; 5 = always another language). If students indicated that they sometimes, often or always speak another language with at least one of their parents, they were regarded as LMi students. Students who mostly or always speak Dutch (i.e. the LOI) with both of their parents were considered as LMa students. These students belong to the group of students having the LOI as their home language and a foreign language as the OL in E-Validiv. For LMi students, it was determined if the OL available to them in E-Validiv matched their home language (i.e. one of the languages one of both parents indicated as being most proficient in). LMi students not having their home language available in E-Validiv were excluded from the analyses. Students also had to judge their own proficiency in their home language (i.e. understanding, speaking, reading, and writing) by giving a score on a 5 -point Likert-scale ( $1=$ very poor; $5=$ very strong). A mean score was calculated for the answer on the four questions. LMi students were first asked what other languages they know, next to the LOI. They could fill in two different languages and assess themselves on the four skills mentioned above. If one of these languages was consistent with a language one of both parents had identified as being most proficient in, it was considered as the student's home language. For LMa students, their score on the selfassessed proficiency in the LOI was used as these students use the same language at home as the LOI.

Background characteristics with regard to gender $(1=$ girl, 2 = boy) and SES were also derived from the student survey. For SES, the international socioeconomic index of occupational status (ISEI08) was calculated (Ganzeboom, de Graaf, \& Treiman, 1992). This index is determined by both parents' profession and has a maximum score of 100 . When parents did not fill in the survey, the index was based on students' answers.

With regard to the characteristics related to learning achievement, both reading performance and science achievement were taken into account. For reading performance, students completed a reading comprehension test from the Dutch Institute for Test Development (Cito) (Staphorsius \& Krom, 1998). Students had to read three fictional texts and answer 20 multiple-choice questions about these texts. For science achievement, the test was derived from The International Mathematics and Science Study (TIMSS), and more specifically from the released Dutch science items from 2003 (Brusselmans-Dehairs \& Valcke, 2004). Students had to solve 34 multiple-choice items concerning earth science, life science, and physics. For both tests, one point was given for a rights answer and zero points for a wrong answer, with a total score of respectively 20 points and 34 points.

\subsubsection{Explanatory variables at classroom level}

To measure the presence of linguistic diversity in the classroom, both the inverse Herfindahl-index and the proportion of LMi students in the classroom was calculated. Using the information on students' home languages, the index was calculated on the basis of every linguistic group present in the classroom: $1-(($ percentage linguistic group 1$)^{2}+(\text { percentage linguistic group } 2)^{2}+\ldots+$ (percentage linguistic group $n)^{2}$ ). A value of 0 indicates that there is no linguistic diversity in the classroom: all students speak the same language at home. A value approximating 1 implies a high linguistic diversity, with different students using different languages at home. However, the inverse Herfindahl-index has been criticized for not taking into account the direction of the diversity (Dronkers 
\& van der Velden, 2013). For example, a classroom with 10\% Italianspeaking LMi students and 90\% LMa students will result in the same value for the inverse Herfindahl-index as a classroom with $90 \%$ Italian-speaking LMi students and 10\% LMa students. As a counterbalance, the proportion of LMi students was also measured. First, it was determined how many students in the classroom have the status of LMi students. This number of students was divided by the total number of students in the classroom.

The positive use of linguistic diversity by the teacher was measured through four items on a 5 -point Likert scale ( $1=$ never; 5 = very often) in the teacher survey. These items ask whether students are allowed to use another language than the LOI (1) to explain something to a peer, (2) during group work, (3) in the classroom, and (4) on the playground. A mean score was calculated for the answer on the four questions.

\subsection{Data analysis}

The data structure is characterized by 250 students (level 1) nested within 35 classrooms (level 2). Because of this hierarchical structure, we opted to study the relationship between both student and classroom characteristics and students' use of the bilingual content in E-Validiv (i.e. the proportion of duration in both languages and the proportion of the use of the language switch button to switch to one of both languages) through multilevel hierarchical regression analyses (MLwiN 2.32).

First, an unconditional model with two levels (i.e. student and classroom) and no predictors was estimated. Next, the characteristics related to students' home language were integrated, namely students' status in E-Validiv, the self-assessed proficiency in their home language, and an interaction between these variables. This was followed by the addition of student background characteristics (i.e., gender, SES) and student characteristics regarding learning achievement (i.e. reading performance, science achievement). Finally, classroom characteristics concerning the presence of linguistic diversity (i.e. inverse Herfindahl-index, proportion of LMi students) and the positive use of linguistic diversity by the teacher were respectively included. This approach enables to decide on the added value of each group of variables. The iterative generalized least squares algorithm was applied for parameter estimation. The comparison of each model's deviance with the previous one determines whether the newly estimated model with extra predictors fits the data better.

\section{Results}

\subsection{Descriptive results of students' use of the bilingual content in E-} Validiv

The means and standard deviations for all variables, together with their Pearson's bivariate correlations, can be found in Table 1 for the student (level 1) variables and in Table 2 for the classroom (level 2) variables.

On average, students have spent $18.66 \mathrm{~min}$ to go through the subtheme under study, with a standard deviation of 9.93, a minimum of $2.15 \mathrm{~min}$ and a maximum of $62.53 \mathrm{~min}$. When taking a closer look at how students access the content provided to them in the two different languages, the descriptive results in Table 3 show that students generally devote $76.71 \%$ of their time to the content in the LOI compared to $23.29 \%$ to the OL. They also switch $78.18 \%$ of the times to the LOI and only $21.82 \%$ of the times to the OL. A similar picture can be found when the results are split up according to students' status in E-Validiv, namely LMi students who have their home language available in E-Validiv as the OL and LMa students for whom the $\mathrm{OL}$ is a foreign language. Although LMi students spend more time in the $\mathrm{OL}(\mathrm{M}=30.24)$ and also switch more often to the $\mathrm{OL}(\mathrm{M}=24.70)$, compared to LMa students $(\mathrm{M}=15.52$ and $M=18.60$, respectively), LMi students' focus also remains on the content offered in the $\mathrm{LOI}(\mathrm{M}=69.76$ and $\mathrm{M}=75.30$, respectively). In the next sections, these results are further analyzed by means of multilevel modeling.

\subsection{Multilevel analysis for the proportion of duration in the $\mathrm{OL}$}

A summary of the stepwise multilevel approach with all model estimates, unstandardized regression coefficients, and standard errors for the proportion of time spent in the OL can be found in Table 4. ${ }^{1}$ In the first step, the fully unconditional two-level null random intercepts model with the proportion of time spent in respectively the OL and LOI as response variable (Model 0) shows that a multilevel approach is justified. While $72.4 \%$ of the variance in the proportion of time spent in both languages emerges from differences between students within classrooms $\left(\sigma_{\mathrm{e} 0}^{2}=429.453\right.$, $\left.\chi^{2}=109.006, \mathrm{df}=1, \mathrm{p}<.001\right), 27.6 \%$ comes from differences between classrooms $\left(\sigma_{\mathrm{u} 0}^{2}=163.589, \chi^{2}=7.812, \mathrm{df}=1, \mathrm{p}<.01\right)$. The addition of variance at the classroom level significantly improves the model $\left(\chi^{2}=35.242, \mathrm{df}=1, \mathrm{p}<.001\right)$.

Students' status in E-Validiv was entered into Model 1, with LMa students having the LOI as their home language and a foreign language as the OL in E-Validiv as reference category. LMi students for whom the OL in E-Validiv is their home language spend more time in the OL and less time in the LOI than LMa students $\left(\chi^{2}=10.556, \mathrm{df}=1, \mathrm{p}<.01\right)$. Model 1 gives a significant better fit for the data than Model $0\left(\chi^{2}=9.753, \mathrm{df}=1, \mathrm{p}<.01\right)$. The self-assessed proficiency in the home language was included in Model 2. Especially students who assess themselves more highly on the proficiency in their home language spend more time in the OL, irrespective of the fact that the OL in E-Validiv is their home language (for LMi students) or a foreign language (for LMa students) $\left(\chi^{2}=11.944, \mathrm{df}=1, \mathrm{p}<.001\right)$. Model 2 gives a significant better fit for the data than Model $1\left(\chi^{2}=92.700, \mathrm{df}=1, \mathrm{p}<.001\right)$. The integration of the interaction term of students' status in E-Validiv on the one hand and the proficiency in the home language on the other hand in Model 3 gives an indication of whether LMi students who assess themselves highly on the proficiency in their home language use the bilingual content in a distinct way. Whereas the main effect of the proficiency in the home language disappears $\left(\chi^{2}=0.031, \mathrm{df}=1, \mathrm{p}>.05\right)$, LMi students who think highly of their proficiency in their home language dedicate more time to the $\mathrm{OL}$, compared to LMa students $\left(\chi^{2}=6.169, \mathrm{df}=1, \mathrm{p}<.05\right)$. The addition of the interaction term significantly improves the model $\left(\chi^{2}=6.085, \mathrm{df}=1, \mathrm{p}<.05\right)$. Including the student background characteristics in Model 4 shows that gender $\left(\chi^{2}=0.288, \mathrm{df}=1\right.$, $\mathrm{p}>.05)$ and SES $\left(\chi^{2}=0.445, \mathrm{df}=1, \mathrm{p}>.05\right)$ do not play a significant role for the time dedicated to both languages. Nevertheless, Model 4 gives a significant better fit for the data than Model $3\left(\chi^{2}=37.100\right.$, $\mathrm{df}=2, \mathrm{p}<.001)$. The inclusion of student characteristics related to learning achievement in Model 5 shows that students who achieve higher on science topics spend more time in the LOI $\left(\chi^{2}=5.584\right.$, $\mathrm{df}=1, \mathrm{p}<.05$ ). Moreover, Model 5 gives a significant better fit for the data than Model $4\left(\chi^{2}=29.872, \mathrm{df}=2, \mathrm{p}<.001\right)$.

Regarding the classroom-level explanatory variables (level 2),

\footnotetext{
${ }^{1}$ As the duration in the OL and the LOI is expressed in proportions, the results on the time spent in the OL give the exact opposite of the results on the time spent in the LOI. For example, when the value for the variable 'proficiency in the home language' is positive for the duration in the OL, the value for 'proficiency in the home language' for the duration in the LOI is precisely the same but negative. For reasons of conciseness, only the table with the results on the proportion of time spent in the OL is included.
} 
Table 1

Descriptive statistics and Pearson's bivariate correlates for level 1 variables.

\begin{tabular}{|c|c|c|c|c|c|c|c|c|c|c|c|}
\hline & $\mathrm{M}(\mathrm{SD})$ & 1 & 2 & 3 & 4 & 5 & 6 & 7 & 8 & 9 & 10 \\
\hline 1. Student status in E-Validiv & - & 1 & & & & & & & & & \\
\hline 2. Proficiency home language & $4.28(0.68)$ & $-0.36^{* * *}$ & 1 & & & & & & & & \\
\hline 3. Gender & - & -0.06 & 0.11 & 1 & & & & & & & \\
\hline 4. SES & $51.06(22.63)$ & $-0.34^{* * *}$ & 0.10 & 0.04 & 1 & & & & & & \\
\hline 5. Reading performance & $12.17(5.05)$ & $-0.33^{* * *}$ & $0.24^{* * *}$ & $-0.15^{*}$ & $0.40^{* * *}$ & 1 & & & & & \\
\hline 6. Science achievement & $21.86(4.93)$ & $-0.37^{* * *}$ & $0.28^{* * *}$ & 0.09 & $0.35^{* * *}$ & $0.61^{* * *}$ & 1 & & & & \\
\hline 7. Proportion time OL & $23.29(24.19)$ & $0.30^{* * *}$ & 0.06 & 0.04 & -0.02 & 0.01 & $-0.13^{*}$ & 1 & & & \\
\hline 8. Proportion time LOI & $76.71(24.19)$ & $-0.30^{* * *}$ & -0.06 & -0.04 & 0.02 & -0.01 & $0.13^{*}$ & $-1.00^{* * *}$ & 1 & & \\
\hline 9. Use LSB to OL & $21.82(21.03)$ & $0.15^{*}$ & 0.06 & -0.02 & -0.06 & 0.00 & $-0.17^{* *}$ & $0.60^{* * *}$ & $-0.60^{* * *}$ & 1 & \\
\hline 10. Use LSB to LOI & $78.18(21.03)$ & $-0.15^{*}$ & -0.06 & 0.02 & 0.06 & 0.00 & $0.17^{* *}$ & $-0.60^{* * *}$ & $0.60^{* * *}$ & $-1.00^{* * *}$ & 1 \\
\hline
\end{tabular}

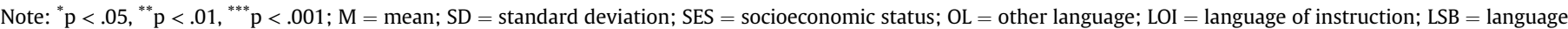
switch button.

Table 2

Descriptive statistics and Pearson's bivariate correlates for level 2 variables.

\begin{tabular}{|c|c|c|c|c|}
\hline & $\mathrm{M}(\mathrm{SD})$ & 1 & 2 & 3 \\
\hline 1. Linguistic diversity: Inverse Herfindahl-index & $0.50(0.19)$ & 1 & & \\
\hline 2. Linguistic diversity: Proportion of LMi students & $0.58(0.35)$ & $0.50^{* * *}$ & 1 & \\
\hline 3. Positive use of linguistic diversity by teacher & $2.07(0.75)$ & $0.22^{* *}$ & 0.01 & 1 \\
\hline
\end{tabular}

Note: ${ }^{*} \mathrm{p}<.05,{ }^{* *} \mathrm{p}<.01,{ }^{* * *} \mathrm{p}<.001 ; \mathrm{M}=$ mean; $\mathrm{SD}=$ standard deviation; $\mathrm{LMi}=$ language minority.

Table 3

Mean and standard deviation for use of bilingual content (i.e. proportion of duration and proportion of use of language switch button).

\begin{tabular}{|c|c|c|}
\hline & $\begin{array}{l}\text { Proportion of duration in OL } \\
M(S D)\end{array}$ & $\begin{array}{l}\text { Proportion of use of language switch button to go to OL } \\
\text { M (SD) }\end{array}$ \\
\hline General & $23.29(24.19)$ & $21.82(21.03)$ \\
\hline LMi students (with match between HL and OL E-Validiv) & $30.24(28.65)$ & $24.70(23.42)$ \\
\hline LMa students & $15.52(14.53)$ & $18.60(17.53)$ \\
\hline
\end{tabular}

Note: $\mathrm{M}=$ mean; $\mathrm{SD}=$ standard deviation; $\mathrm{LMi}=$ language minority; $\mathrm{LMa}=$ language majority; $\mathrm{HL}=$ home language; $\mathrm{OL}=$ other language.

the classroom characteristics concerned with the presence of linguistic diversity were added first in Model 6. Although the inverse Herfindahl-index for linguistic diversity $\left(\chi^{2}=0.217, \mathrm{df}=1, \mathrm{p}>.05\right)$ does not explain variance in the time spent in both languages, the proportion of LMi students relates positively to the proportion of time dedicated to the $\mathrm{OL}\left(\chi^{2}=7.815, \mathrm{df}=1, \mathrm{p}<.01\right)$. Model 6 gives a significant better fit for the data than Model $5\left(\chi^{2}=7.771, \mathrm{df}=1\right.$, $\mathrm{p}<.05$ ). The positive use of linguistic diversity by the teacher was included in Model 7. However, this parameter does not have added value to explain variance in the proportion of time spent in the $\mathrm{OL}$ and the LOI $\left(\chi^{2}=0.285, \mathrm{df}=1, \mathrm{p}<.05\right)$. Moreover, the presence of LMi students in the classroom is no longer significantly related to the dependent variables once the use of linguistic diversity by the teacher is included. Nevertheless, Model 7 gives a significant better fit for the data than Model $6\left(\chi^{2}=206.431, \mathrm{df}=1, \mathrm{p}<.001\right)$.

\subsection{Multilevel analysis for the use of the language switch button to go to the $O L$}

Table 5 gives an overview of the stepwise multilevel approach with all model estimates, unstandardized regression coefficients, and standard errors for the proportion of time spent in the $\mathrm{OL}^{2}$. The fully unconditional two-level null random intercepts model with

\footnotetext{
2 In line with the duration in the OL and the LOI, the use of the language switch button to go to the OL or the LOI is expressed in proportions. Therefore, the results on the use of the language switch button to switch to the OL give the exact opposite of the results on the use of the language switch button to switch to the LOI. Accordingly, only the table with the results on the proportion of use of the language switch button to go to the OL is included.
}

the proportion of the use of the language switch button to switch respectively to the $\mathrm{OL}$ or the LOI as response variable (Model 0) shows that the choice for a multilevel approach is supported. While $81.5 \%$ of the variance in the proportion of the use of the language switch button is related to differences between students within classrooms $\left(\sigma_{\mathrm{e} 0}^{2}=361.782, \chi^{2}=109.667, \mathrm{df}=1, \mathrm{p}<.001\right), 18.5 \%$ stems from differences between classrooms $\left(\sigma_{\mathrm{u} 0}^{2}=82.290\right.$, $\left.\chi^{2}=5.675, \mathrm{df}=1, \mathrm{p}<.05\right)$. Adding variance at the classroom level significantly improves the model $\left(\chi^{2}=18.802, \mathrm{df}=1, \mathrm{p}<.001\right)$.

Students' status in E-Validiv was included in Model 1. Apparently, LMi students who have their home language available in EValidiv make similar use of the language switch button as LMa students to switch between languages $\left(\chi^{2}=2.954, \mathrm{df}=1, \mathrm{p}>.05\right)$. Moreover, Model 1 does not give a significant better fit for the data than Model $0\left(\chi^{2}=2.875, \mathrm{df}=1, \mathrm{p}>.05\right)$. The self-assessed proficiency in the home language was entered into Model 2, showing that a higher self-assessed proficiency in the home language is related to a higher proportion of switches to the OL, regardless of whether students have their home language or a foreign language available in E-Validiv $\left(\chi^{2}=5.634, \mathrm{df}=1, \mathrm{p}<.05\right)$. Moreover, the addition of this factor indicates that LMi students having their home language available in E-Validiv switch more often to the OL when the self-assessed proficiency in the home language is taken into account $\left(\chi^{2}=7.162, \mathrm{df}=1, \mathrm{p}<.01\right)$. Model 2 gives a better fit for the data than Model $1\left(\chi^{2}=81.492\right.$, $\left.\mathrm{df}=1, \mathrm{p}<.001\right)$. The interaction term of students' status in E-Validiv and the proficiency in the home language was integrated in Model 3. However, this interaction term does not seem to play a significant role to explain the use of the language switch button $\left(\chi^{2}=0.718, \mathrm{df}=1, \mathrm{p}>.05\right)$. Moreover, the main effect of the proficiency in the home language 
Table 4

Unstandardized regression coefficients and standard errors from the random intercept model (dependent variable: proportion of duration in the other language).

\begin{tabular}{|c|c|c|c|c|c|c|}
\hline & Single level & Model 0 & Model 1 & Model 2 & Model 3 & Model 4 \\
\hline \multicolumn{7}{|l|}{ Fixed part } \\
\hline Intercept(cons) & $23.290(1.527)^{* * *}$ & $23.074(2.697)^{* * *}$ & $16.736(3.109)^{* * *}$ & $14.477(3.282)^{* * *}$ & $16.253(3.295)^{* * *}$ & $15.191(3.589)^{* * *}$ \\
\hline \multicolumn{7}{|l|}{ Student level } \\
\hline $\begin{array}{l}\text { Student status in E-Validiv (ref. cat.: LMa } \\
\text { students) }\end{array}$ & & & $11.006(3.388)^{* *}$ & $16.443(3.634)^{* * *}$ & $15.643(3.598)^{* * *}$ & $17.086(3.760)^{* * *}$ \\
\hline Proficiency home language & & & & $7.266(2.102)^{* * *}$ & $-0.672(3.812)$ & $-0.917(3.814)$ \\
\hline $\begin{array}{l}\text { Interaction Student status in E- } \\
\quad \text { Validiv } \times \text { Proficiency home language }\end{array}$ & & & & & $11.247(4.528)^{*}$ & $12.055(4.560)^{* *}$ \\
\hline Gender (ref. cat.: girl) & & & & & & $1.461(2.720)$ \\
\hline SES & & & & & & $0.047(0.070)$ \\
\hline \multicolumn{7}{|l|}{ Reading performance } \\
\hline \multicolumn{7}{|l|}{ Science achievement } \\
\hline \multicolumn{7}{|l|}{ Classroom level } \\
\hline \multicolumn{7}{|l|}{ Linguistic diversity: Inverse Herfindahl-index } \\
\hline \multicolumn{7}{|l|}{ Linguistic diversity: Proportion of LMi students } \\
\hline \multicolumn{7}{|l|}{ Positive use of linguistic diversity by teacher } \\
\hline \multicolumn{7}{|l|}{ Random part } \\
\hline Classroom level $\sigma_{\mathrm{u} 0}^{2}$ (between) & & $163.589(58.528)^{* *}$ & $119.001(46.661)^{*}$ & $140.784(52.020)^{* *}$ & $132.596(49.854)^{* *}$ & $123.282(47.532)^{* *}$ \\
\hline Student level $\sigma_{\mathrm{e} 0}^{2}$ (within) & $582.894(52.136)^{* * *}$ & $429.453(41.133)^{* * *}$ & $423.982(40.526)^{* * *}$ & $395.544(38.665)^{* * * *}$ & $386.995(37.788)^{* * *}$ & $386.912(38.136)^{* * *}$ \\
\hline \multicolumn{7}{|c|}{ (2) } \\
\hline Deviance(-2LL) & 2301.471 & 2266.229 & 2256.476 & 2163.776 & 2157.691 & 2120.591 \\
\hline$\chi^{2}$ & & 35.242 & 9.753 & 92.700 & 6.085 & 37.100 \\
\hline df & & 1 & 1 & 1 & 1 & 2 \\
\hline $\mathrm{p}$ & & $* * *$ & $* *$ & $* * *$ & $*$ & $* * *$ \\
\hline Reference model & & Single level & Model 0 & Model 1 & Model 2 & Model 3 \\
\hline \multicolumn{7}{|l|}{ Variance at level 2} \\
\hline \multirow[t]{2}{*}{$\rho(\%)$} & & $27.6 \%$ & $21.9 \%$ & $26.2 \%$ & $25.5 \%$ & $24.2 \%$ \\
\hline & & \multicolumn{2}{|c|}{ Model 5} & \multicolumn{2}{|l|}{ Model 6} & Model 7 \\
\hline \multicolumn{7}{|l|}{ Fixed part } \\
\hline \multicolumn{2}{|l|}{ Intercept(cons) } & \multicolumn{2}{|c|}{$15.088(3.574)^{* * *}$} & \multicolumn{2}{|c|}{$16.801(3.555)^{* * *}$} & $17.442(3.799)^{* * *}$ \\
\hline \multicolumn{7}{|l|}{ Student level } \\
\hline \multicolumn{2}{|l|}{ Student status in E-Validiv (ref. cat.: LMa students) } & 16.123 & $3(3.770)^{* * *}$ & $11.620(4.086$ & $6)^{* *}$ & $12.188(4.290)^{* *}$ \\
\hline Proficiency home language & & -0.81 & $9(3.882)$ & $-1.090(3.822$ & & $-2.494(4.486)$ \\
\hline Interaction Student status in E-Validiv $\times$ Proficie & ncy home language & 12.418 & $8(4.579)^{* *}$ & $11.251(4.529$ & & $13.037(5.120)^{*}$ \\
\hline Gender (ref. cat.: girl) & & 2.848 & $(2.867)$ & $3.178(2.824)$ & & $2.717(3.065)$ \\
\hline SES & & 0.060 & $(0.073)$ & $0.083(0.072)$ & & $0.071(0.079)$ \\
\hline Reading performance & & 0.443( & $(0.380)$ & $0.520(0.376)$ & & $0.533(0.414)$ \\
\hline Science achievement & & -0.87 & $8(0.371)^{*}$ & $-0.783(0.36$ & & $-0.889(0.393)^{*}$ \\
\hline Classroom level & & & & & & \\
\hline Linguistic diversity: Inverse Herfindahl-index & & & & $-6.441(13.8$ & 18) & $1.262(15.804)$ \\
\hline Linguistic diversity: Proportion of LMi students & & & & $19.335(6.916$ & $6)^{* *}$ & $12.111(9.817)$ \\
\hline Positive use of linguistic diversity by teacher & & & & & & $1.840(3.446)$ \\
\hline Random part & & & & & & \\
\hline Classroom level $\sigma^{2}{ }_{\mathrm{u} 0}($ between $)$ & & 113.6 & $72(44.950)^{*}$ & $106.813(42.7$ & $760)^{*}$ & $109.069(45.199)^{*}$ \\
\hline Student level $\sigma_{\mathrm{e} 0}^{2}$ (within) & & 384.00 & $07(38.115)^{* * *}$ & $372.479(36.9$ & $953)^{* * *}$ & $384.110(40.371)^{* * *}$ \\
\hline Model fit & & & & & & \\
\hline Deviance(-2LL) & & 2090.7 & 719 & 2082.948 & & 1876.517 \\
\hline$\chi^{2}$ & & 29.87 & & 7.771 & & 206.431 \\
\hline df & & 2 & & 2 & & 1 \\
\hline $\mathrm{p}$ & & $* * *$ & & * & & $* * *$ \\
\hline Reference model & & Model & & Model 5 & & Model 6 \\
\hline Variance at level 2 & & & & & & \\
\hline$\rho(\%)$ & & $22.8 \%$ & & $22.3 \%$ & & $22.1 \%$ \\
\hline
\end{tabular}

Note: ${ }^{*} \mathrm{p}<.05,{ }^{* *} \mathrm{p}<.01,{ }^{* * *} \mathrm{p}<.001 ;$ values in parentheses are standard errors; $\mathrm{HL}=$ home language; $\mathrm{LMa}=$ language majority; $\mathrm{SES}=$ socioeconomic status.

disappears $\left(\chi^{2}=0.342, \mathrm{df}=1, \mathrm{p}>.05\right)$. The addition of the interaction term does not lead to a significant improvement of Model 3 in comparison to Model $2\left(\chi^{2}=0.713, \mathrm{df}=1, \mathrm{p}>.05\right)$. Although gender $\left(\chi^{2}=0.064, \mathrm{df}=1, \mathrm{p}>.05\right)$ and SES $\left(\chi^{2}=0.081, \mathrm{df}=1\right.$, $\mathrm{p}>.05)$ do not play a significant role in the use of the language switch button, the inclusion of student background characteristics in Model 4 leads to a significant better fit for the data $\left(\chi^{2}=-37.111\right.$, $\mathrm{df}=2, \mathrm{p}<.001)$. With regard to the integration of student characteristics related to learning achievement, Model 5 shows that students who achieve higher results for science also switch more often to the LOI $\left(\chi^{2}=13.845, \mathrm{df}=1, \mathrm{p}<.001\right)$. Model 5 fits the data significantly better than Model $4\left(\chi^{2}=40.004 . \mathrm{df}=2, \mathrm{p}<.001\right)$.

The addition of the classroom-level explanatory variables (level 2 ) concerned with the presence of linguistic diversity in Model 6 leads to the disappearance of the significant positive fixed slope for students' status in E-Validiv $\left(\chi^{2}=1.747, \mathrm{df}=1, \mathrm{p}>.05\right)$. Moreover, the resulting Model 6 does not give a significant better fit for the data than Model $5\left(\chi^{2}=2.386, \mathrm{df}=2, \mathrm{p}>.05\right)$. The positive use of linguistic diversity by the teacher was added in Model 7. However, the included parameter does not have added value to explain variance in the use of the language switch button to switch between languages $\left(\chi^{2}=1.168, \mathrm{df}=1, \mathrm{p}>.05\right)$. Nevertheless, Model 7 gives a significant better fit for the data than Model 6 $\left(\chi^{2}=-207.435, \mathrm{df}=1, \mathrm{p}<.001\right)$.

\section{Discussion and conclusion}

\subsection{Discussion}

Whereas LMi students' home language is now still often 
Table 5

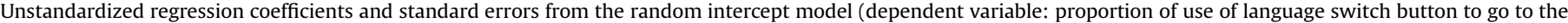
other language).

\begin{tabular}{|c|c|c|c|c|c|c|}
\hline & Single level & Model 0 & Model 1 & Model 2 & Model 3 & Model 4 \\
\hline \multicolumn{7}{|l|}{ Fixed part } \\
\hline Intercept(cons) & $21.823(1.328)^{* * *}$ & $21.787(2.088)^{* * *}$ & $18.812(2.659)^{* * *}$ & $17.265(2.725)^{* * *}$ & $17.871(2.799)^{* * *}$ & $18.086(3.187)^{* * *}$ \\
\hline \multicolumn{7}{|l|}{ Student level } \\
\hline $\begin{array}{l}\text { Student status in E-Validiv (ref. cat.: LMa } \\
\text { students) }\end{array}$ & & & $5.208(3.030)$ & $8.758(3.272)^{* *}$ & $8.458(3.281)^{* *}$ & $9.438(3.465)^{* *}$ \\
\hline Proficiency home language & & & & $4.715(1.986)^{*}$ & $2.127(3.637)$ & $2.213(3.620)$ \\
\hline \multicolumn{7}{|l|}{ Validiv $\times$ Proficiency home language } \\
\hline Gender (ref. cat.: girl) & & & & & & $-0.650(2.577)$ \\
\hline SES & & & & & & $0.019(0.065)$ \\
\hline \multicolumn{7}{|l|}{ Reading performance } \\
\hline \multicolumn{7}{|l|}{ Science achievement } \\
\hline \multicolumn{7}{|l|}{ Classroom level } \\
\hline \multicolumn{7}{|l|}{ Linguistic diversity: Inverse Herfindahl-index } \\
\hline \multicolumn{7}{|l|}{ Linguistic diversity: Proportion of LMi students } \\
\hline \multicolumn{7}{|l|}{ Positive use of linguistic diversity by teacher } \\
\hline \multicolumn{7}{|l|}{ Random part } \\
\hline Classroom level $\sigma_{\text {uo }}^{2}$ (between) & & $82.290(34.542)^{*}$ & $73.442(32.047)^{*}$ & $71.968(32.120)^{*}$ & $69.680(31.492)^{*}$ & $74.635(32.904)^{*}$ \\
\hline Student level $\sigma_{\mathrm{e} 0}^{2}$ (within) & $440.574(39.406)^{* * *}$ & $361.782(34.547)^{* * *}$ & $360.573(34.414)^{* * *}$ & $357.662(34.828)^{* * *}$ & $357.428(34.796)^{* * *}$ & $352.308(34.650)^{* * *}$ \\
\hline \multicolumn{7}{|c|}{ ( } \\
\hline Deviance(-2LL) & 2231.489 & 2212.687 & 2209.812 & 2128.32 & 2127.607 & 2090.496 \\
\hline$\chi^{2}$ & & 18.802 & 2.875 & 81.492 & 0.713 & 37.111 \\
\hline df & & 1 & 1 & 1 & 1 & 2 \\
\hline $\mathrm{p}$ & & $* * *$ & & *** & & *** \\
\hline Reference model & & Single level & Model 0 & Model 1 & Model 2 & Model 3 \\
\hline \multicolumn{7}{|l|}{ Variance at level 2} \\
\hline \multirow[t]{2}{*}{$\rho(\%)$} & & $18.5 \%$ & $16.9 \%$ & $16.8 \%$ & $16.3 \%$ & $17.5 \%$ \\
\hline & & \multicolumn{2}{|c|}{ Model 5} & \multicolumn{2}{|l|}{ Model 6} & Model 7 \\
\hline \multicolumn{7}{|l|}{ Fixed part } \\
\hline \multicolumn{2}{|l|}{ Intercept(cons) } & \multicolumn{2}{|c|}{$18.181(3.202)^{* * *}$} & \multicolumn{2}{|c|}{$19.146(3.240)^{* * *}$} & $18.803(3.422)^{* * *}$ \\
\hline \multicolumn{7}{|l|}{ Student level } \\
\hline Student status in E-Validiv (ref. cat.: LMa student & & 7.544( & $3.435)^{*}$ & $5.024(3.802)$ & & $5.887(3.956)$ \\
\hline Proficiency home language & & 2.150( & $3.578)$ & $2.026(3.562)$ & & $1.367(4.134)$ \\
\hline Interaction Student status in E-Validiv $\times$ Proficier & ncy home language & 4.800( & $4.223)$ & $4.176(4.223)$ & & $5.548(4.723)$ \\
\hline Gender (ref. cat.: girl) & & 0.987( & $2.640)$ & $1.166(2.630)$ & & $0.924(2.825)$ \\
\hline SES & & 0.033( & $0.067)$ & $0.045(0.067)$ & & $0.083(0.073)$ \\
\hline Reading performance & & 0.504( & $0.349)$ & $0.546(0.349)$ & & $0.451(0.380)$ \\
\hline Science achievement & & -1.27 & $2(0.342)^{* * *}$ & $-1.220(0.342$ & $2)^{* * *}$ & $-1.391(0.362)^{* * *}$ \\
\hline Classroom level & & & & & & \\
\hline Linguistic diversity: Inverse Herfindahl-index & & & & $-0.849(12.31$ & 16) & $9.353(13.878)$ \\
\hline Linguistic diversity: Proportion of LMi students & & & & $9.565(6.345)$ & & $4.790(8.702)$ \\
\hline Positive use of linguistic diversity by teacher & & & & & & $-3.266(3.021)$ \\
\hline Random part & & & & & & \\
\hline Classroom level $\sigma_{\text {uo }}^{2}$ (between) & & 81.005 & $5(33.864)^{*}$ & 79.001(33.29 & $91)^{*}$ & $77.900(34.364)^{*}$ \\
\hline Student level $\sigma_{\mathrm{e} 0}^{2}$ (within) & & 328.31 & $14(32.570)^{* * *}$ & $325.406(32.2$ & $268)^{* * *}$ & $328.909(34.538)^{* * *}$ \\
\hline Model fit & & & & & & \\
\hline Deviance(-2LL) & & 2050.4 & 492 & 2048.106 & & 1840.671 \\
\hline$\chi^{2}$ & & 40.004 & & 2.386 & & 207.435 \\
\hline df & & 2 & & 2 & & 1 \\
\hline $\mathrm{p}$ & & *** & & & & *** \\
\hline Reference model & & Model & & Model 5 & & Model 6 \\
\hline Variance at level 2 & & & & & & \\
\hline$\rho(\%)$ & & $19.8 \%$ & & $19.5 \%$ & & $19.1 \%$ \\
\hline
\end{tabular}

Note: ${ }^{*} \mathrm{p}<.05,{ }^{* *} \mathrm{p}<.01,{ }^{* * *} \mathrm{p}<.001$; values in parentheses are standard errors; $\mathrm{HL}=$ home language; LMa = language majority; SES $=$ socioeconomic status.

excluded from the learning process, CBLEs offer great potential to integrate it as a valuable support tool in the classroom practice (e.g. Clark et al., 2012). This can offer a way to close the gap in science achievement between LMi students and LMa students (Martin et al., 2012; OECD, 2009, 2010; Van Laere et al., 2014). In this study, we explored how students approach bilingual content (i.e. content in the language of instruction (LOI) and one of six other languages (OLs), according to students' home language) offered in E-Validiv, a CBLE dealing with science topics. Moreover, we identified both student and classroom characteristics related to the use of the bilingual content. Therefore, we examined the time spent in both languages as well as the related activity of code-switching through the use of a language switch button. Special focus was put on LMi students, as they have their home language available in the CBLE.

In general, the content in the OL is accessed by both LMi and LMa students. Thus, while LMi students make use of their home language, LMa students also tend to go to the foreign language. This can indicate that LMa students are curious about the content in the foreign language and even make connections between both languages as they often already have some notion of the foreign language through the use of different media (Kuppens, 2007). Through comparing the content in both languages, their metalinguistic awareness can be stimulated, thereby strengthening their insight into how language works (Kenner et al., 2008; Martin-Beltrán, 2010). Furthermore, LMi students tend to spend more time in and 
switch more often to their home language than LMa students do with regard to the foreign language. However, LMi students' main focus also remains on the content offered in the LOI as they still spend a little less than three-quarters of their time in the LOI. This may imply that they use both the content in the home language and code-switching strategically (Macaro, 2005; Moodley, 2007; Upton \& Lee-Thompson, 2001).

The findings from the multilevel analyses confirm that especially the student characteristics related to LMi students' home language characterize the use of the bilingual content: LMi students spend more time in their home language, compared to the time LMa students dedicate to the foreign language. At the same time, LMi students are still directed mostly at the LOI, which indicates that they especially apply the content offered in their home language as a support tool for their learning process (Clark et al., 2012; Jiménez et al., 1996; Msimanga \& Lelliott, 2014; Van Laere, Rosiers, Van Avermaet, Slembrouck, \& van Braak, 2015). Furthermore, selfassessed proficiency in the home language only plays a role for LMi students' use of the bilingual support: while LMi students generally dedicate more time to their home language, those who assess themselves as more highly proficient in their home language spend even more time in their home language than LMi students who do not think highly of their competence in their home language. While Moreno and Duran (2004) found that students with limited proficiency in the LOI access explanations in a CBLE more in their home language, our study shows that students who assess themselves as highly proficient in their home language approach the content more in their home language. The latter thus seem to feel more confident in using their home language as a support for their learning process. Accordingly, they may profit more from it as research has already indicated that students who are highly proficient in their home language benefit from it for their academic achievement in the LOI (Yeung et al., 2000). However, for E-Validiv, this needs to be further examined in studies with a focus on outcomes related to science achievement.

The activity of code-switching, operationalized as the use of the language switch button, cannot be sufficiently explained by the characteristics related to LMi students' home language. Research has shown that code-switching is a common and purposefully used skill in bilinguals which fosters deep knowledge and skill acquisition in content areas across and between languages (Celic \& Seltzer, 2011; Macaro, 2005; Unamuno, 2008). However, in E-Validiv, LMi and LMa students do not seem to apply code-switching in a distinct way to access content in either language. We acknowledge that accurately capturing code-switching in a CBLE through the use of a language switch button may be very hard as it is mostly an automatic process in highly competent bilinguals (Macaro, 2005). However, students may also need explicit encouragement to develop and apply code-switching in a CBLE like E-Validiv before they can appeal to it as a true learning strategy (Duibhir \& Cummins, 2012; Ferguson, 2009; Jiménez et al., 1996; Reyes, 2004). As Söderberg Arnfast and Jørgensen (2003) state, students first need to be taught how and when to use code-switching strategically before it can support their learning process.

With regard to the other student characteristics, only students' science achievement is significantly related to the way the bilingual content is approached: students who already master science content rather well access the content more in the LOI than in the OL. In other words, LMa students who already perform well on science topics seem to be less inclined to attend to the content in the foreign language. Moreover, high achieving LMi students are probably less in need of deploying their home language as a support tool for learning as they already have a good understanding of the content in the LOI. This supports the idea that particularly low achieving LMi students need assistance in their home language to bridge the achievement gap between LMi and LMa students (Martin et al., 2012; OECD, 2009, 2010; Van Laere et al., 2014). Whereas reading comprehension in the LOI has been shown to be related to both science achievement (Maerten-Rivera et al., 2010; O'Reilly \& McNamara, 2007; Taboada, 2012; Van Laere et al. 2014) and how content in CBLEs is approached (Snow et al., 2014), it does not play a significant role in the way the bilingual content in the CBLE E-Validiv is accessed. Although Moreno and Duran (2004) found that students with limited proficiency in the LOI turned more often to explanations in their home language in a CBLE, this was not confirmed in this study for reading performance in the LOI. Furthermore, whereas Pöhnl and Bogner (2012) found the same instructional design to be used differently according to gender, boys and girls tend to apply the bilingual content in EValidiv in a similar way. Whether a student comes from a family with a high or a low SES does not influence the way the bilingual content is approached, which is in line with the findings from Tondeur and colleagues (2011).

With regard to the classroom characteristics, the findings show that differences between classrooms indeed exist in the way the bilingual content is used in a CBLE like E-Validiv. However, the possible reasons that have been put forward in this study cannot give sufficient explanation. For example, the presence of a large linguistic diversity in the classroom may help students to open up to different languages (Gogolin, 2002). As a consequence, they may be triggered to access the content in the OL more. However, whether or not a classroom consists of different groups of students speaking a variety of languages does not explain why students in various classrooms approach the bilingual content in E-Validiv differently. Moreover, it could be expected that when teachers give room to every student's linguistic repertoire and intentionally use it in the learning process (Sierens \& Van Avermaet, 2014; Muller \& Baetens Beardsmore, 2004), this also influences the way students approach the content in the OL in E-Validiv. However, this could not be confirmed in the present study.

\subsection{Implications}

In sum, particularly the characteristics related to LMi students' home language play a role in the way the bilingual content in EValidiv is approached. This is especially the case for the time dedicated to both languages; it remains unclear which characteristics explain differences in the way code-switching is deployed. Compared to LMa students, LMi students tend to use the content in their home language more while their main focus remains on the content in the LOI. This indicates that LMi students especially apply the content in their home language as a support for knowledge acquisition in the LOI. However, we must take into account that the overall limited use of LMi students' support in their home language may also reflect a more general caution in these students in applying the resources in their home language in the classroom context. At the start of our study, the majority of the participating schools were in favor of a monolingual approach and did not question it. Hence, the focus in nearly all classrooms was on learning in and through the LOI, which implies that LMi students received the message to exclude their home language from their learning process. The implementation of the newly developed CBLE E-Validiv, with LMi students gaining access to content available in their home language, introduced a whole new approach. Students may not yet have felt comfortable enough to strategically apply their home language as a valuable tool for learning within the given context. As research has already shown, the setting may have an important influence on whether or not the home language is used (e.g. Becker, 1997; Goriot et al., 2015; Gort, 2006; Storch \& Wigglesworth, 2003). Moreover, this may explain why we did not 
find any relationship between the factors related to the linguistic diversity in the classroom and the use of the bilingual content in EValidiv. As nearly all classrooms started the project with a monolingual approach in which the present linguistic diversity was not made visible or intentionally employed, they were comparable in this respect. Therefore, investments in informing both teachers and their students of what students' linguistic repertoire in general, and the home language in particular, can contribute to the learning process, is a necessary prerequisite for the present linguistic diversity to be valued as a didactic resource (Goriot et al., 2015). In this way, multilingual CBLEs like E-Validiv can be intentionally employed in both teachers' classroom practice and students' learning process.

Furthermore, LMi students with a low self-assessed proficiency in their home language who struggle with science content seem to face challenges in applying bilingual content efficiently. Special attention should be given to this group in order to strengthen both their home language and the LOI, which is in line with Cummins' (1979) linguistic interdependence hypothesis. With regard to the development of E-Validiv, this can imply that the content is made more concrete (e.g. through animations, videos, ...) and that support is adapted according to students' competence (e.g. explanation of difficult words, facilitating content, ...). Introducing a multilingual approach from early childhood education onwards can also help to let students benefit from their full linguistic repertoire at a later age. In combination with sufficient professional support and a continued development of a clear vision on the positive use of linguistic diversity, this can lead CBLEs such as E-Validiv to become a viable tool in tackling the challenges today's linguistically diverse classrooms are faced with.

\subsection{Limitations and future directions}

A number of limitations of the present study and related directions for future research should be taken into account. First, the use of the bilingual content is studied for only one subtheme in EValidiv. The activity in other subthemes could also be analyzed to examine if the results can be replicated. Second, students themselves judged their proficiency in their home language. A more accurate measure of this factor could be obtained through the use of standardized tests. However, in the context of the present study, this was not possible because of the large linguistic diversity in our sample and the lack of comparable tests of sufficient quality for the different languages. Related to this, LMa students' proficiency in the foreign language available to them in E-Validiv could also be taken into account in future studies, as this can influence the way they approach the information in the other language. Third, no conclusions can be drawn with regard to causal relationships as our data were not collected in the context of a longitudinal design. Moreover, future studies with a focus on achievement are needed to examine if the use of CBLEs, such as E-Validiv, can contribute to students' learning outcomes. Fourth, we have only employed data based on the logging to analyze students' activities in the CBLE. Qualitative data (e.g. observations, interviews, ...) could shed more light on students' motives to use the bilingual content. Finally, it remains unclear which classroom characteristics may influence the use of the bilingual content in the CBLE. Future research should explore other classroom characteristics (e.g. the way the CBLE is integrated into the classroom practice) to get a clearer picture of what may cause differences between classrooms. The use of qualitative data can be helpful here too.

\section{Conclusion}

To conclude, the present study contributes to the general understanding of different characteristics which play a role in the way students approach CBLEs. This can support the design of more effective CBLEs and give insights into how we can prepare students to pursue their learning goals through the strategic use of various supports (Proctor et al., 2007). More specifically, this study gives unique first insights into what relates to students' use of bilingual content offered to them in a CBLE by means of switching between languages. It shows that a CBLE such as E-Validiv may act as a viable means to support LMi students in their learning process through integrating their home language. Furthermore, it offers promising pathways to explore in what way the science achievement gap between LMi and LMa students can be bridged. In sum, the development of E-Validiv, and of multilingual CBLEs in general, can be regarded as a valuable starting point to approach the existing linguistic diversity in the classroom as an asset instead of a burden.

\section{Acknowledgment}

This work was supported by the Agency for Innovation by Science and Technology (IWT), Flanders (Belgium) under Grant 110008 (Valorizing Linguistic Diversity in Multiple Contexts of Primary Education “Validiv”).

\section{References}

Aesaert, K., \& van Braak, J. (2015). Gender and socioeconomic related differences in performance based ICT competences. Computers \& Education, 84, 8-25.

Agirdag, O. (2010). Exploring bilingualism in a monolingual school system: insights from Turkish and native students from Belgian schools. British Journal of Sociology of Education, 31, 307-321.

Alegría de la Colina, A., \& del Pilar García Mayo, M. (2009). Oral interaction in taskbased EFL learning: the use of the L1 as a cognitive tool. IRAL - International Review of Applied Linguistics in Language Teaching, 47, 325-345.

Auerbach, E. R. (1993). Reexamining English only in the ESL classroom. TESOL Quarterly, 27, 9-32.

August, D., Carlo, M., Dressler, C. \& Snow, C. (2005). The critical role of vocabulary development for English language Learners. Learning Disabilities Research \& Practice, 20, 50-57.

Baker, C. (2011). Foundations of bilingual education and bilingualism (5th ed.). Bristol, UK: Multilingual Matters.

Becker, K. R. (1997). Spanish/English bilingual codeswitching: a syncretic model. The Bilingual Review, 22, 3-30.

Bellens, K., Arkens, T., Van Damme, J., \& Gielen, S. (2013). Sociale ongelijkheid en ongelijkheid op basis van thuistaal inzake wetenschapsprestaties in het vlaamse onderwijs-Veranderingen tussen 2003 en 2011 op basis van TIMSS, $4^{\text {de }}$ leerjaar [Social inequality and inequality on the basis of the home language with regard to science achievement in Flemish education-Changes between 2003 and 2011 on the basis of TIMSS, 4th grade]. Leuven: Steunpunt Studie- en Schoolloopbanen.

Bialystok, E., \& Hakuta, K. (1999). Confounded age: linguistic and cognitive factors in age differences for second language acquisition. In D. Birdsong (Ed.), Second language acquisition and the critical period hypothesis (pp. 161-181). Mahwah, NJ: Lawrence Erlbaum.

Bono, M., \& Melo-Pfeifer, S. (2010). Language negotiation in multilingual learning environments. International Journal of Bilingualism, 15, 291-309.

van Braak, J., \& Kavadias, D. (2005). The influence of social-demographic determinants on secondary school children's computer use, experience, beliefs and competence. Technology, Pedagogy and Education, 14, 43-59.

Brusselmans-Dehairs, C., \& Valcke, M. (2004). TIMSS 2003: Grade 4 Vrijgegeven items Wetenschappen [TIMSS 2003: Grade 4 Released items Sciences]. Ghent: Department of Educational Studies, Ghent University.

Butler, K. A., \& Lumpe, A. (2008). Student use of scaffolding software: relationships with motivation and conceptual understanding. Journal of Science Education and Technology, 17, 427-436.

Butzkamm, W. (1998). Code-switching in a bilingual history lesson: the mother tongue as a conversational lubricant. International Journal of Bilingual Education and Bilingualism, 1, 81-99.

Canagarajah, S. (2011). Codemeshing in academic writing: Identifying teachable strategies of translanguaging. The Modern Language Journal, 95, 401-417.

Celic, C., \& Seltzer, K. (2011). Translanguaging: A CUNY-NYSIEB guide for educators. New York, NJ: CUNY - NYSIEB, The Graduate Center, The City University of New York.

Chanseawrassamee, S., \& Shin, S. J. (2009). Participant- and discourse-related codeswitching by Thai-English bilingual adolescents. Multilingua-Journal of CrossCultural and Interlanguage Communication, 28, 45-78.

Chitera, N. (2009). Code-switching in a college mathematics classroom. International Journal of Multilingualism, 6, 426-442.

Clarebout, G., \& Elen, J. (2006). Tool use in computer-based learning environments: 
towards a research framework. Computers in Human Behavior, 22, 389-411.

Clark, D. B., Touchman, S., Martinez-Garza, M., Ramirez-Marin, F. \& Drews, T. S. (2012). Bilingual language supports in online science inquiry environments. Computers \& Education, 58, 1207-1224.

Cook, V. (2001). Using the first language in the classroom. The Canadian Modern Language review, 57, 402-423.

Cummins, J. (1979). Linguistic interdependence and the educational development of bilingual children. Bilingual Education Paper Series, 3(2), 2-69.

Cummins, J. (2001). Bilingual children's mother tongue: why is it important for education? SPROG forum, 19, 15-20.

Curenton, S. M., \& Justice, L. M. (2004). African American and Caucasian preschoolers' use of decontextualized language: literate language features in oral narratives. Language, Speech, and Hearing Services in Schools, 35, 240-253.

Dalton, B., \& Proctor, C. P. (2007). Reading as thinking: Integrating strategy instruction in a universally designed digital literacy environment. In D. S. McNamara (Ed.), Reading comprehension strategies: Theories, interventions, and technologies (pp. 421-439). Mahwah, NJ: Lawrence Erlbaum Associates.

Dronkers, J., \& van der Velden, R. (2013). Positive but also negative effects of ethnic diversity in schools on educational performance? an empirical test using PISA data. In M. Windzio (Ed.), Integration and inequality in educational institutions (pp. 71-98). Dordrecht: Springer Science/Business Media.

Duibhir, P., \& Cummins, J. (2012). Towards an integrated language curriculum in early childhood and primary education (3-12 years) - Commissioned research report. Dublin: National Council for Curriculum and Assessment.

Edwards, V., Monaghan, F., \& Knight, J. (2000). Books, pictures and conversations: Using bilingual multimedia storybooks to develop language awareness. Language Awareness, 9, 135-146.

Fang, Z. (2006). The language demands of science reading in middle school. International Journal of Science Education, 28, 491-520.

Farrell, M. P. (2011). Bilingual competence and students' achievement in physics and mathematics. International Journal of Bilingual Education and Bilingualism, 14, $335-345$.

Ferguson, G. (2003). Classroom code-switching in post-colonial contexts: functions, attitudes and policies. AILA Review, 16, 38-51.

Ferguson, G. (2009). What next? towards an agenda for classroom codeswitching research. International Journal of Bilingual Education and Bilingualism, 12, $231-241$.

Freeman, B. (2012). Using digital technologies to redress inequities for English language learners in the English speaking mathematics classroom. Computers \& Education, 59, 50-62.

Freeman, B., \& Crawford, L. (2008). Creating a middle school mathematics curriculum for English-language learners. Remedial and Special Education, 29, 9-19.

Fung, I. Y., Wilkinson, I. A., \& Moore, D. W. (2003). L1-assisted reciprocal teaching to improve ESL students' comprehension of English expository text. Learning and Instruction, 13, 1-31.

Ganzeboom, H. B. G., de Graaf, P. M., \& Treiman, D. J. (1992). A standard international socio-economic index of occupational status. Social Science Research, 21, $1-56$.

Genesee, F., Geva, E., Dressler, C., \& Kamil, M. (2006). Synthesis: cross-linguistic relationships. In D. August, \& D. Shanahan (Eds.), Developing literacy in second-language learners (pp. 153-174). Mahwah, NJ: Lawrence Erlbaum.

Gogolin, I. (2002). Linguistic and cultural diversity in Europe: a challenge for educational research and practice. European Educational Research Journal, 1, 123-138.

Goldenberg, C. (2008). Teaching English language Learners: what the research does - and does not - say. American Educator, 32(2), 8-44.

Goodrich, J. M. G., Lonigan, C. J., \& Farver, J. M. (2013). Do early literacy skills in children's first language promote development of skills in their second language? an experimental evaluation of transfer. Journal of Educational Psychology, 105, 414-426.

Goriot, C., Denessen, E., Bakker, J., \& Droop, M. (2015). Benefits of being bilingual? the relationship between pupils' perceptions of teachers' appreciation of their home language and executive functioning. International Journal of Bilingualism, 1-14. http://dx.doi.org/10.1177/1367006915586470.

Gort, M. (2006). Strategic codeswitching, interliteracy, and other phenomena of emergent bilingual writing: lessons from first grade dual language classrooms. Journal of Early Childhood Literacy, 6, 323-354.

Gort, M. (2012). Code-switching patterns in the writing-related talk of young emergent bilinguals. Journal of Literacy Research, 44, 45-75.

Greene, J. A., \& Azevedo, R. (2007). A theoretical review of Winne and Hadwin's model of self-regulated learning: new perspectives and directions. Review of Educational Research, 77, 334-372.

Grimley, M. (2007). Learning from multimedia materials: the relative impact of individual differences. Educational Psychology, 27, 465-485.

Grosjean, F. (1998). Studying bilinguals: methodological and conceptual issues. Bilingualism: Language and Cognition, 1, 131-149.

Hannafin, M. J., \& Land, S. M. (1997). The foundations and assumptions of technology-enhanced student-centered learning environments. Instructional Science, 25, 167-202.

Hiebert, E. H., \& Lubliner, S. (2008). The nature, learning, and instruction of general academic vocabulary. In A. E. Farstrup, \& S. J. Samuels (Eds.), What research has to say about vocabulary instruction. Newark, DE: International Reading Association.

Jiménez, R. T. (2000). Literacy and the identity development of latina/o students. American Educational Research Journal, 37, 971-1000.
Jiménez, R. T., García, G. E., \& Pearson, P. D. (1995). Three children, two languages, and strategic reading: case studies in bilingual/monolingual reading. American Educational Research Journal, 32, 67-97.

Jiménez, J. E., García, G. E., \& Pearson, P. D. (1996). The reading strategies of bilingua latina/o students who are successful English readers: opportunities and obstacles. Reading Research Quarterly, 31, 90-112.

Kempert, S., Saalbach, H., \& Hardy, I. (2011). Cognitive benefits and costs of bilingualism in elementary school students: the case of mathematical word problems. Journal of Educational Psychology, 103, 547-561.

Kenner, C., Gregory, E., Ruby, M., \& Al-Azami, S. (2008). Bilingual learning for second and third generation children. Language. Culture and Curriculum, 21, 120-137.

Klois, S. S., Segers, E., \& Verhoeven, L. (2013). How hypertext fosters children's knowledge acquisition: the roles of text structure and graphical overview. Computers in Human Behavior, 29, 2047-2057.

Kuppens, A. (2007). De invloed van mediagebruik op de verwerving van Engelse woordenschat: een empirische studie bij Vlaamse jongeren [The influence of media use on the acquisition of English vocabulary: an empirical study with Flemish youth]. Tijdschrift voor Communicatiewetenschap, 35, 325-336.

Lajoie, S. P., \& Azevedo, R. (2006). Teaching and learning in technology-rich environments. In P. A. Alexander, \& P. H. Winne (Eds.), Handbook of educational psychology (2nd ed., pp. 803-821). Mahway, NJ: Lawrence Erlbaum Associates.

Lanauze, M., \& Snow, C. (1989). The relation between first- and second-language writing skills: evidence from Puerto Rican elementary school children in bilingual programs. Linguisticas and Education, 1, 323-339.

Langer, J. A., Bartolome, L., Vasquez, O., \& Lucas, T. (1990). Meaning construction in school literacy tasks: a study of bilingual students. American Educational Research Journal, 27, 427-471.

Lantolf, J. P. (2000). Second language learning as a mediated process. Language Teaching, 33, 79-96.

Lantolf, J. P., \& Thorne, S. L. (2007). Sociocultural theory and second language learning. In B. van Patten, \& J. Williams (Eds.), Theories in second language acquisition (pp. 201-224). Mahwah, NJ: Lawrence Erlbaum Associates.

Liebscher, G., \& Dailey-O'Cain, J. (2005). Learner code-switching in the contentbased foreign language classroom. The Modern Language Journal, 89, 234-247.

Losey, K. M. (2009). Written codeswitching in the classroom: can research resolve the tensions? International Journal of Bilingual Education and Bilingualism, 12, $213-230$.

Macaro, E. (2005). Codeswitching in the L2 classroom: a communcation and learning strategy. In E. Llurda (Ed.), Non-native language teachers: Perceptions, challenges and contributions to the profession (pp. 63-84). Boston, MA: Springer.

Maerten-Rivera, J., Myers, N., Lee, O., \& Penfield, R. (2010). Student and school predictors of high-stakes assessment in science. Science Education, 94, 937-962.

Martin-Beltrán, M. (2010). The two-way language bridge: co-constructing bilingua language learning opportunities. The Modern Language Journal, 94, 254-277.

Martin, M. O., Mullis, I. V. S., Foy, P., \& Stanco, G. M. (2012). TIMSS 2011 international results in science. Chestnut Hill, MA: TIMSS \& PIRLS International Study Center, Boston College.

Moodley, V. (2007). Codeswitching in the multilingual English first language classroom. International Journal of Bilingual Education and Bilingualism, 10, 707-722.

Moore, D. (2002). Code-switching and learning in the classroom. International Journal of Bilingual Education and Bilingualism, 5, 279-293.

Moreno, R., \& Duran, R. (2004). Do multiple representations need explanations? the role of verbal guidance and individual differences in multimedia mathematics learning. Journal of Educational Psychology, 96, 492-503.

Msimanga, A., \& Lelliott, A. (2014). Talking science in multilingual contexts in South Africa: possibilities and challenges for engagement in learners' home languages in high school classrooms. International Journal of Science Education, 36, 1159-1183.

Muller, A., \& Baetens Beardsmore, H. (2004). Multilingual interaction in plurilingual classes - European school practice. Bilingual Education and Bilingualism, 7, 24-42.

Ng, S., Gonzalez, C., \& Wicha, N. Y. Y. (2014). The fox and the cabra: an ERP analysis of reading code switched nouns and verbs in bilingual short stories. Brain Research, 1557, 127-140.

O'Reilly, T., \& McNamara, D. S. (2007). The impact of science knowledge, reading skill, and reading strategy knowledge on more traditional "high-stakes" measures of high school students' science achievement. American Educational Research Journal, 44, 161-196.

Organisation for Economic Co-operation and Development (OECD). (2009). Top of the Class: High performers in science in PISA 2006. Paris: OECD.

Organisation for Economic Co-operation and Development (OECD). (2010). PISA 2009 results: Overcoming social background - Equity in learning opportunities and outcomes (Volume II). Paris: OECD.

Pea, R. D. (2004). The social and technological dimensions of scaffolding and related theoretical concepts for learning, education, and human activity. Journal of the Learning Sciences, 13(3), 423-451.

Pederson, K. M. (1986). An experiment in computer-assisted second-language reading. The Modern Language Journal, 70, 36-41.

Pöhnl, S., \& Bogner, F. X. (2012). Learning with computer-based multimedia: gender effects on efficiency. Journal of Educational Computing Research, 47, 387-407.

Poplack, S. (1980). Sometimes I'll start a sentence in Spanish y termino en Español: toward a typology of code-switching. Linguistics, 18, 581-618.

Proctor, C. P., August, D., Carlo, M. S., \& Snow, C. (2006). The intriguing role of Spanish language vocabulary knowledge in predicting English reading 
comprehension. Journal of Educational Psychology, 98, 159-169.

Proctor, C. P., Carlo, M., August, D., \& Snow, C. (2005). Native Spanish-speaking children reading in English: toward a model of comprehension. Journal of Educational Psychology, 97, 246-256.

Proctor, C. P., Dalton, B., \& Grisham, D. L. (2007). Scaffolding English language learners and struggling readers in a universal literacy environment with embedded strategy instruction and vocabulary support. Journal of Literacy research, 39, 71-93.

Proctor, C. P., Dalton, B., Uccelli, P., Biancarosa, G., Mo, E., Snow, C., et al. (2011). Improving comprehension online: effects of deep vocabulary instruction with bilingual and monolingual fifth graders. Reading and Writing, 24, 517-544.

Reyes, I. (2004). Functions of code switching in schoolchildren's conversations. Bilingual Research Journal, 28, 77-98.

Riches, C., \& Genesee, F. (2006). Literacy: crosslinguistic and crossmodal issues. In F. Genesee, K. Lindholm-Leary, W. Saunders, \& D. Christian (Eds.), Educating english language learners: A synthesis of research evidence (pp. 64-108). New York, NJ: Cambridge University Press.

Riegelhaupt, F. (2000). Codeswitching and language use in the classroom. In A. Roca (Ed.), Research on Spanish in the U.S (pp. 204-217). Somerville, MA: Cascadilla Press.

Scott, V. M., \& de la Fuente, M. J. (2008). What's the problem? L2 learners' use of the L1 during consciousness-raising, form-focused tasks. The Modern Language Journal, 92, 100-113.

Shanahan, T., \& Shanahan, C. (2008). Teaching disciplinary literacy to adolescents: rethinking content-area literacy. Harvard Educational Review, 78, 40-59.

Shannon, S. M. (1995). The hegemony of English: a case study of one bilingual classroom as a site of resistance. Linguistics and Education, 7, 175-200.

Sierens, S., \& Van Avermaet, P. (2014). Language diversity in education: evolving from multilingual education to functional multilingual learning. In D. Little, C. Leung, \& P. Van Avermaet (Eds.), Managing diversity in education: Languages, policies, pedagogies (pp. 204-222). Bristol, UK: Multilingual Matters.

Snow, E. L., Jackson, G. T., \& McNamara, D. S. (2014). Emergent behaviors in computer-based learning environments: computational signals of catching up. Computers in Human Behavior, 41, 62-70.

Söderberg Arnfast, J., \& Jørgensen, J. N. (2003). Code-switching as a communication, learning, and social negotiation strategy in first-year learners of Danish. International Journal of Applied Linguistics, 13, 23-53.

Staphorsius, G., \& Krom, R. S. H. (1998). Toetsen Begrijpend Lezen (Handleiding [Tests Reading Achievement: Manual]. Arnhem: Citogroep).

Storch, N., \& Wigglesworth, G. (2003). Is there a role for the use of the L1 in an L2 setting? TESOL Quarterly, 37, 760-770.

Swain, M., \& Lapkin, S. (2000). Task-based second language learning: the uses of the first language. Language Teaching Research, 4, 251-274.
Taboada, A. (2012). Relationships of general vocabulary, science vocabulary, and student questioning with science comprehension in students with varying levels of English proficiency. Instructional Science, 40, 901-923.

Tondeur, J., Sinnaeve, I., Van Houtte, M., \& van Braak, J. (2011). ICT as cultural capital: the relationship between socioeconomic status and the computer-use profile of young people. New Media \& Society, 13, 151-168.

Unamuno, V. (2008). Multilingual switch in peer classroom interaction. Linguistics and Education, 19, 1-19.

Upton, T. A., \& Lee-Thompson, L.-C. (2001). The role of the first language in second language reading. Studies in Second Language Acquisition, 23, 469-495.

Van den Branden, K. (2010). Handboek taalbeleid basisonderwijs [Handbook language policy primary education]. Leuven: Acco.

Van Laere, E., Aesaert, K., \& van Braak, J. (2014). The role of students' home language in science achievement: a multilevel approach. International Journal of Science Education, 36, 2772-2794.

Van Laere, E., Rosiers, K., Van Avermaet, P., Slembrouck, S., \& van Braak, J. (2015). What can technology offer to linguistically diverse classrooms? Using multilingual content in a computer-based learning environment for primary education. Manuscript submitted for publication.

Volman, M., van Eck, E., Heemskerk, I., \& Kuiper, E. (2005). New technologies, new differences. Gender and ethnic differences in pupils' use of ICT in primary and secondary education. Computers \& Education, 45, 35-55.

Vygotsky, L. S. (1978). Mind in society: The development of higher psychological processes. Cambridge, MA: Harvard University Press.

Wang, L. (2003). Switching to first language among writers with differing secondlanguage proficiency. Journal of Second Language Writing, 2003, 347-375.

Wang, X. (2015). Language control in bilingual language comprehension: evidence from the maze task. Frontiers in Psychology, 6, 1-12.

Willans, F. (2011). Classroom code-switching in a Vanuatu secondary school: conflict between policy and practice. International Journal of Bilingual Education and Bilingualism, 14, 23-38.

Wood, D., Bruner, J., \& Ross, G. (1976). The role of tutoring in problem solving. Journal of Child Psychology and Psychiatry, 17, 89-100.

Yeung, A. S., Marsh, H. W., \& Suliman, R. (2000). Can two tongues live in harmony: analysis of the national education longitudinal study of 1988 (NELS88) longitudinal data on the maintenance of home language. American Educational Research Journal, 37, 1001-1026.

Zhang, X., Gao, Y., Yan, X., Ordóñez de Pablos, P., Sun, Y., \& Cao, X. (2015). From elearning to social-learning: mapping development of studies on social mediasupported knowledge management. Computers in Human Behavior, 51, 803-811.

Zhang, X., Ordóñez de Pablos, P., \& Xu, Q. (2014). Culture effects on the knowledge sharing in multi-national virtual classes: a mixed method. Computers in Human Behavior, 31, 491-498. 